Pesq. Vet. Bras. 37(2):110-114, fevereiro 2017

DOI: $10.1590 / \mathrm{S} 0100-736 \mathrm{X} 2017000200003$

\title{
Spontaneous poisoning by Prosopis juliflora (Leguminosae) in sheep ${ }^{1}$
}

\author{
Valdir M. Almeida², Brena P. Rocha², James A. Pfister ${ }^{3}$, Rosane M.T. Medeiros ${ }^{4}$, \\ Franklin Riet-Correa ${ }^{5}$, Hisadora A.S. Chaves ${ }^{6}$, Givaldo B. Silva Filho ${ }^{6}$ \\ and Fábio S. Mendonça ${ }^{6 *}$
}

\begin{abstract}
Almeida V.M., Rocha B.P., Pfister J.A., Medeiros R.M.T., Riet-Correa F., Chaves H.A.S., Silva Filho G.B. \& Mendonça F.S. 2017. Spontaneous poisoning by Prosopis juliflora (Leguminosae) in sheep. Pesquisa Veterinária Brasileira 37(2):110-114. Universidade Federal Rural de Pernambuco, Rua Dom Manoel de Medeiros s/n, Dois Irmãos, Recife, PE 52171-900, Brazil. E-mail: fabio.mendonca@pq.cnpq.br

The aim of this paper is to describe the first report of spontaneous poisoning by Prosopis juliflora in sheep. From flock of 500 sheep at risk, four adult male sheep were affected. One died spontaneously and three other were examined, euthanized and necropsied. Neurologic examination focused particularly on motor and sensory-cranial nerve function, complete blood counts, serum biochemistry and urinalysis were done. The evolution of the disease was chronic and to present signs of poisoning, sheep had to ingest a diet containing at least $80 \%$ of $P$. juliflora pods during 21 months. The biochemistry revealed a substantial increase in creatine phosphokinase levels. Clinical signs included drooling of saliva, dropped jaw, tongue protrusion and loss of food from the mouth. Gross and histological lesions were similar to those previously reported in cattle and goats. Sheep are more resistant to poisoning by $P$. juliflora considering that it took 21 months of pod consumption to show clinical signs. There is no specific treatment for $P$. juliflora poisoning in ruminants.
\end{abstract}

INDEX TERMS: Poisonous plants, Prosopis juliflora, Leguminosae, mesquite beans, plant poisoning, neuronal vacuolation, sheep.

RESUMO.- [Intoxicação espontânea por Prosopis juliflora (Leguminosae) em ovinos.] 0 objetivo deste trabalho é descrever o primeiro caso de intoxicação espontânea por Prosopis juliflora em ovinos. De um total de 500 ovinos sob risco, quatro ovinos machos adultos foram afetados. Um

\footnotetext{
${ }^{1}$ Recebido em 8 de setembro de 2015.

Aceito para publicação em 25 de agosto de 2016.

${ }^{2}$ Programa de Pós-Graduação em Ciência Veterinária. Departamento de Medicina Veterinária, Universidade Federal Rural de Pernambuco (UFRPE). Rua Dom Manoel de Medeiros, s/n, Dois Irmãos, Recife, PE 52171-900, Brazil.

${ }^{3}$ Poisonous Plant Research Laboratory, Agricultural Research Service, United States. Department of Agriculture, 1150 E. 1400 N., Logan, UT 84341, USA.

${ }^{4}$ Hospital Veterinário, Centro de Saúde e Tecnologia Rural (CSTR), Universidade Federal de Campina Grande, Campus de Patos, Patos, PB 58700000, Brazil.

${ }^{5}$ Estación Experimental La Estanzuela, INIA, Ruta 50, Km 11, Colonia, Uruguay.

${ }^{6}$ Laboratório de Diagnóstico Animal, Departamento de Morfologia e Fisiologia Animal, UFRPE, Recife, PE 52171-900, Brazil. *Corresponding author: fabio.mendonca@pq.cnpq.br
}

ovino morreu espontaneamente e os outros foram examinados, eutanasiados e necropsiados. Realizaram-se exames clínicos direcionados particularmente para funções de nervos motores e sensoriais-craniais. Avaliou-se hemograma, perfil bioquímico sérico e urinálise. A evolução da doença foi crônica e para apresentar sinais de intoxicação os ovinos tiveram que ingerir uma dieta contendo $80 \%$ das vagens de P. Juliflora durante 21 meses. Os níveis de creatinofosfoquinase estavam significativamente elevados. Os sinais clínicos consistiram em sialorreia, mandíbula pendulosa, protusão da língua e perda de alimento pela boca. As lesões macroscópicas e microscópicas foram similares àquelas reportadas previamente em bovinos e caprinos. Ovinos são mais resistentes à intoxicação por $P$. Juliflora, tendo em vista que foi necessário 21 meses de consumo das vagens para que os ovinos apresentassem sinais clínicos. Não há tratamento específico para a intoxicação por $P$. Juliflora em ruminantes.

TERMOS DE INDEXAÇÃO: Plantas tóxicas, Prosopis juliflora, Leguminosae, algaroba, intoxicação por planta, vacuolização neuronal, ovinos. 


\section{INTRODUCTION}

Prosopis juliflora (mesquite beans) (Fig.1A,B) is a xerophilous tree that originated from Peru, Chile and Argentina. The tree was later introduced into east and southern Africa, the Middle East, Central and South America, and the Caribbean. Now P. juliflora occurs between $35^{\circ} \mathrm{N}$ and $4^{\circ} \mathrm{S}$ throughout Western Asia, Africa and arid and semi-arid regions in the Americas, from the southwestern United States to Central Chile and Argentina (Silva 1988).

Despite its nutritional value, $P$. juliflora pods are known to be toxic, mainly for cattle and goats (Tabosa et al. 2000, Tabosa et al. 2006). In horses the pods of this tree causes impaction (Pessoa et al. 2012), whereas sheep are reported to be resistant to the poisoning (Riet-Correa et al. 2012). Spontaneous poisoning by the pods of $P$. juliflora in cattle was reported in USA (Kingsbury 1964), in goats in Peru and in cattle (Câmara et al. 2009) and goats (Lima et al. 2004) in northeastern Brazil. The spontaneous or experimental poisoning of sheep by the pods of $P$. juliflora has not been reported, thus the aim of this paper is to describe the clinical, epidemiologic and pathologic aspects of spontaneous poisoning by the pods of $P$. juliflora in sheep.

\section{MATERIALS AND METHODS}

Epidemiological and clinical data of poisoning by Prosopis juliflo$r a$ in sheep were obtained from the owner and the veterinarian responsible for the flock during a technical visit in a farm at the region of Ipojuca Valley, state of Pernambuco, northeastern Brazil (7 59' 24" S / 36 29' 47" W).

Neurologic examinations performed focused particularly on motor and sensory cranial nerve functions. Complete blood count, serum biochemistry and urinalysis were made. Two $10 \mathrm{~mL}$ tubes were used, one with anticoagulant sodium ethylenediaminetetraacetate (EDTA) in a 10\% aqueous solution and the other without the additive, were used. In the tube with no anticoagulant, serum was separated by centrifugation at $2500 \mathrm{rpm}$ for 10 minutes, and kept at $-20^{\circ} \mathrm{C}$ until analysis.

The biochemical tests were performed using semi-automated commercial enzyme kits for aspartate aminotransferase (AST), creatine phosphokinase (CPK), gamma glutamyl transferase (GGT), urea, creatinine, direct and indirect bilirubin. The hemogram consisted of determining the packed cell volume, the hemoglobin dosage, RBC and total leukocyte counts, and the differential leukocyte count.

Urine was collected in clean glass. The examination of the urine consisted of physical assessment (volume, color, odor and appearance, consistency, presence of sediments and density) and dry chemistry reagent strips were used for the chemistry evaluation of the samples according Lopes et al. (2007).

During necropsy, tissues from abdominal, thoracic cavities, tongue and masseter, pterygoid, styloglossal, hypoglossal, buccinator, and geniohyoid muscles were collected and fixed in 10\% formalin solution. Brain, spinal cord, trigeminal ganglia, peripheral nerves (facial, trigeminal, maxillary, mandibular, hypoglossal and lingual) were fixed in $10 \%$ formalin solution. After being, the fragments were processed according to routine techniques, stained with hematoxylin-eosin (HE) and analyzed histologically.

\section{RESULTS}

The climate in the region where the poisonings by Prosopis juliflora occurred is semi-arid, with high temperatures and scarce and poorly distributed rainfall. The characteristic vegetation is savanna. The property consists of $<100 \mathrm{ha}$, and was grazed with bred Santa Inês sheep. The flock was kept in a semi-confinement system; in the early morning they were loose to graze in a pasture of buffel grass (Cenchrus ciliaris) and in late afternoon received ration prepared in the farm.

From a flock of 500 sheep at risk, four sheep were highly exposed to the plant and presented clinical signs of poisoning. One affected sheep died spontaneously two weeks before the technical visit, and other three animals were examined, euthanized and necropsied during the visit. Four rams used as breeders were routinely kept housed in single stalls in a confinement system. Due to the long period of drought and scarcity of fodder, all the flock started to receive a diet containing a mixture of $80 \%$ of dried ground pods of $P$. juliflora, $10 \%$ of corn and $10 \%$ of wheat. The feeding management of rams was basically composed by this ration. In the end of the day they received a little amount of chopped buffel grass in the trough.

Just the rams presented clinical signs of poisoning. These signs were observed 21 months after the consumption of this diet with a high concentration of $P$. juliflora pods. The rams clinically examined showed depression, drowsiness, dysphagia and motor and sensory cranial nerve dysfunction. Beyond the clinical signs mentioned above there was decreased response of the facial skin to pinprick, nystagmus, head tilting with loss of food while chewing, slack jaw, droopy ears, decreased tongue tone when it was pulled out, and tongue protrusion (Fig.2A,B). Other clinical signs included dehydration, polydipsia, oliguria, and rumen atony. According to the veterinarian of the farm the sheep that died spontaneously had these same clinical signs.

The values of hematology, urinalysis, AST, GGT, urea, creatinine, and direct and indirect bilirubin were within normal ranges. Total plasma protein (average $=11.0 \mathrm{~g} / \mathrm{dL}$ ) and fibrinogen (average $=0.9 \mathrm{~g} / \mathrm{dL}$ ) were slightly increased. Creatine kinase (average $=373 \mathrm{U} / \mathrm{L}$ ) was markely increased. CPK normal values range 8.1-12.9 U/L, Total plasma protein range $6.0-7.9 \mathrm{~g} / \mathrm{dL}$ and fibrinogen $0.1-0.5 \mathrm{~g} / \mathrm{dL}$ (Lopes et al. 2007).

At necropsy the molars teeth were tortuous, had exceeded the plan of occlusion facing the palatal plane and the-

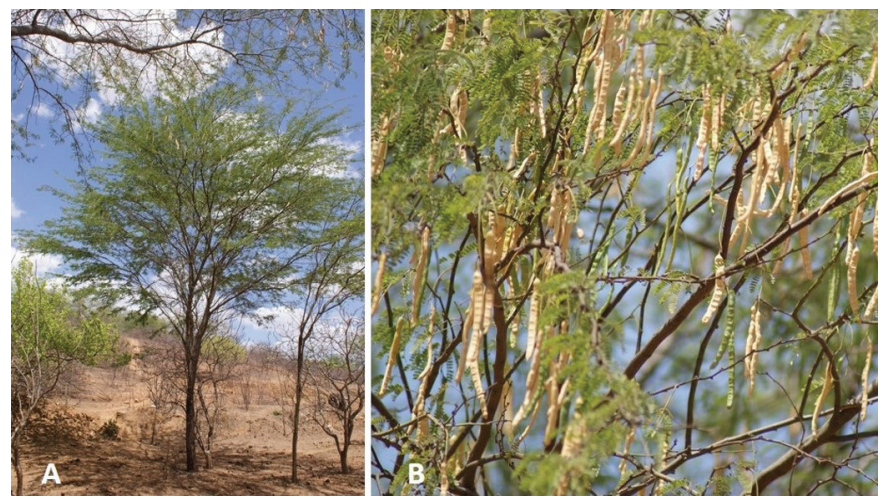

Fig.1. (A) Prosopis juliflora, Jataúba, PE. (B) Detailed view of the leaves and elongated pods showing the chambers and yellowish coloration. 

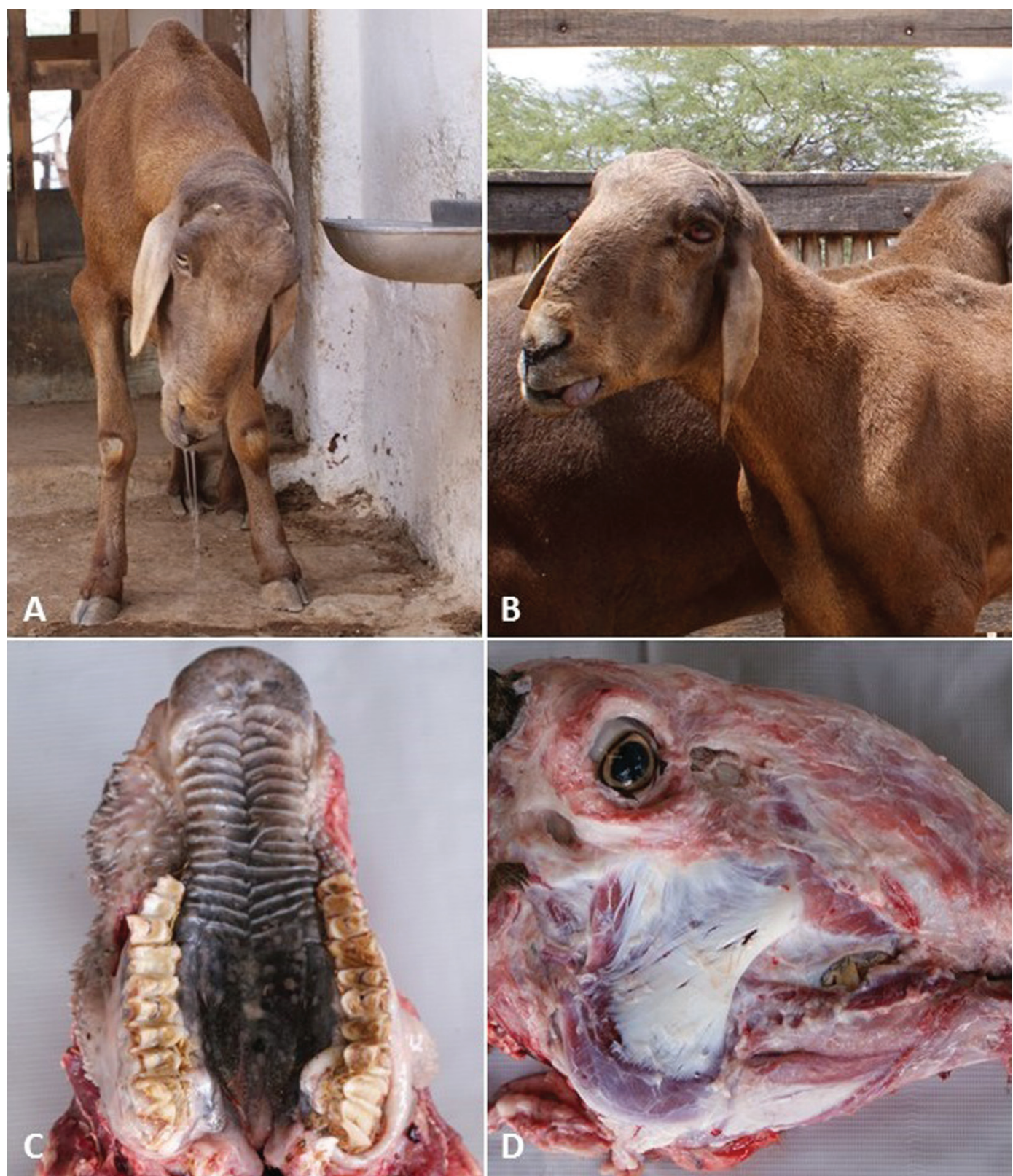

Fig.2. (A) Spontaneous poisoning by Prosopis juliflora. Sheep with depression, drooling, head tilt, and (B) tongue protrusion. (C) Molars exceeding the plane of occlusion, ruined and tilted to the palatine plane. (D) Slight depression of the masseter muscle, suggesting atrophy.

re was atrophy of the gingival mucosa (Fig.2C). In addition there was a decrease in masseter muscle volume (Fig.2D). The contents of the rumen and abomasum were resected and examined, and contained a significant amount of P. juliflora pods. Histologically, muscle fibers of the masseter and tongue showed severe atrophy (Fig.3A). Mild atrophy was also observed in the hypoglossal and buccinator muscles. These muscles had triangular and eosinophilic fibers and in some areas there was connective tissue proliferation. The main histologic lesions in the CNS were observed in the trigeminal motor nuclei and lingual nervous ganglia, and consisted of fine vacuolation of neuron's perikaryon, presence of rare axonal spheroids mild neuronal loss and central chromatolysis. Occasionally, pale neurons (ghost neurons) with dissolution of the Nissl substance and un- defined limits were observed (Fig.3B). In the roots of the trigeminal nerve there was Wallerian degeneration with dilatation of the myelin sheath and the presence of vacuoles occasionally containing axonal debris or macrophages. Mild Wallerian-like degeneration was also observed in the mandibular, hypoglossal, facial and lingual nerves. No significant histologic lesions were observed in the other organs examined.

\section{DISCUSSION AND CONCLUSION}

The diagnosis of natural poisoning by Prosopis juliflora was based on epidemiological data, clinical signs, necropsy and histological findings similar to those described in cattle (Tabosa et al. 2006) and in the history of plant consumption. In cattle, clinical signs of poisoning by P. juliflora are 


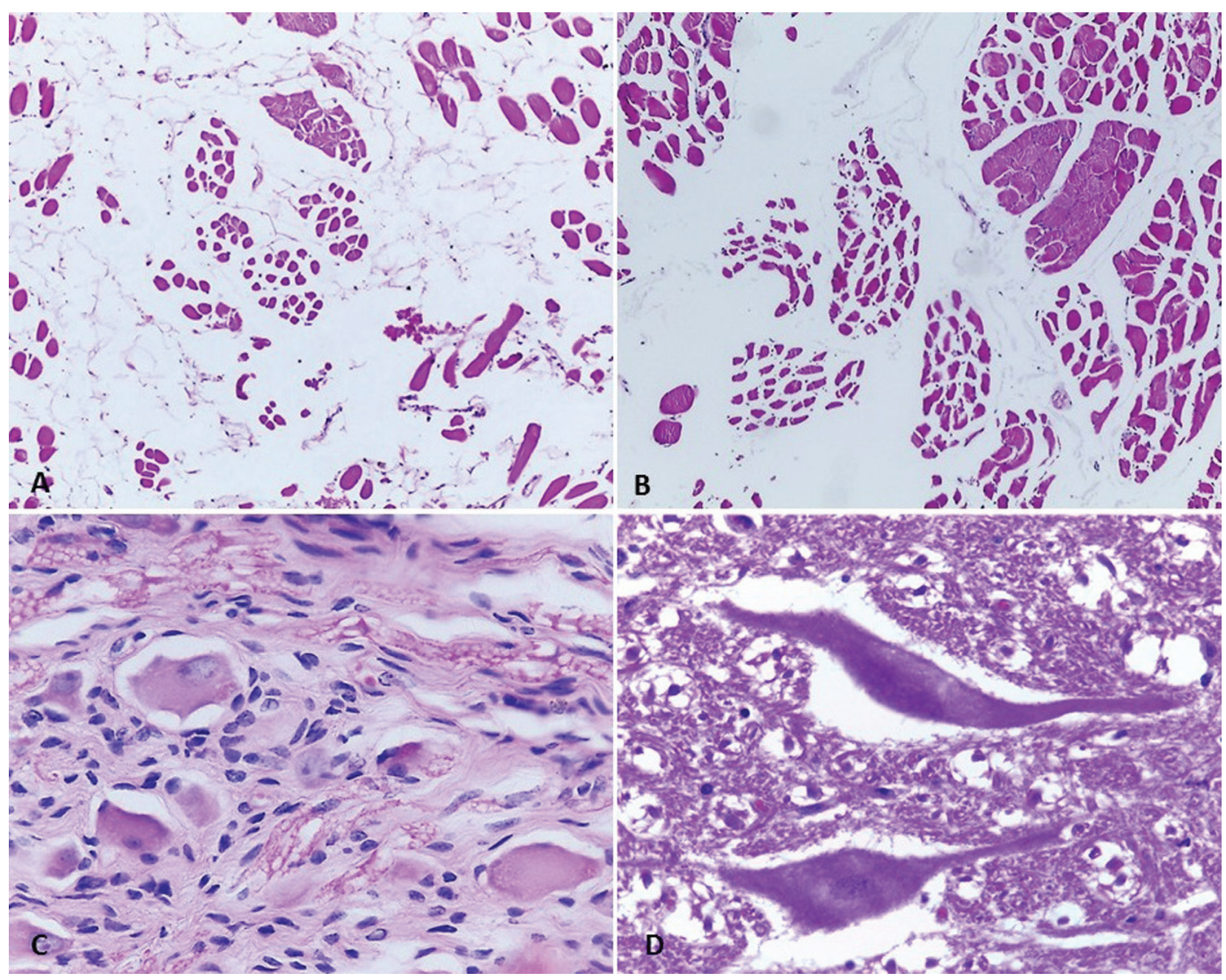

Fig.3. (A) Spontaneous poisoning by Prosopis juliflora in sheep. Tongue with disappearance of many muscle fibers, deltaic and severe atrophy muscle fibers. HE, obj.10x. (B) Severy atrophy of masseter muscle fibers. (C) Discrete vacuolization, mild neuronal loss and central chormatolysis of the lingual nervous ganglia neurons. HE, obj.40x. (D) Neurons of the motor trigeminal nucleus with irregular distribution of Nissl substance. HE, obj.40x.

more evidently during mastication or rumination when sheep shows head tilt, tongue protrusion and salivation. These clinical signs were similar to those observed in sheep of this study. At necropsy, the main lesion is the atrophy of the masseter and buccinator muscles due to degeneration of axons of peripheral nerves (Tabosa et al. 2006, Câmara et al. 2009). These lesions were equally observed in sheep and should be considered. Other diseases like otitis, listeriosis and central nervous system abscesses are common in sheep and must be considered at differential diagnosis. These are the first cases of poisoning by P. juliflora in sheep. The evolution of the disease was chronic and to present signs of poisoning, sheep had to ingest a diet containing at least $80 \%$ of $P$. juliflora pods for a period of 21 months. The morbidity was very low $(0.008 \%)$ considering total number of sheep in this flock. But the system management was different in each animal category. During major part of the day, ewes were grazing and were not exposed to the plant. The rams were kept in their stalls with the ration ad libitum. So, ewes did not ate the same high amounts of ration containing $P$. juliflora than the rams.

It is not clear why sheep in general appear to have greater resistance to poisoning by P. juliflora. Our observations suggest that sheep must ingest the plant for very long periods of time, and this appears to explain the epidemiology of disease among sheep, cattle and goats. In an experiment with sheep receiving a diet containing mesquite beans at $70-100 \%$ of the diet for a year, none of animals were poisoned (Riet-Correa et al. 2012). In cattle, the poisoning was observed after they ingested diets containing $50 \%$ and $75 \%$ pods over $45-75$ days (Tabosa et al. 2000). Apparently goats are more resistant than cattle and to present clinical signs they have to ingest diets consisting of $60-90 \%$ pods over a period of approximately 210 days (Tabosa et al. 2000).

Increased creatine kinase, total plasma protein and fibrinogen are associated with myopathy from the loss of muscle fibers and long periods of recumbence due to P. juliflora poisoning. The clinic and pathological picture developed by sheep consisted mainly of neurological disorders. The most prominent clinical signs were slack jaw, tongue protrusion, and loss of rumen contents during rumination. These changes are characteristic of impaired cranial nerves, especially the trigeminal and facial nerves. Additionally, lesions in the brain stem and thalamus may also cause changes in behavior and posture, such as depression, drowsiness and head tilt (Riet-Correa et al. 2002).

$P$. juliflora contains the piperidine alkaloids juliflorine, julifloricine, julifloridine, juliprosinene, juliflorinine and juliprosopine (Ahmad et al. 1986, Ahmad et al. 1989). While not certain, it appears plausible that the neuromuscular disease observed in poisoned ruminants is caused by some 
combination of these alkaloids. Juliprosopine is present in all parts of the plant, including the fruit (Ahmad et al. 1991) and in a recent study it was demonstrated that this alkaloid interferes with the bioenergetics of rat brain mitochondria, causing a reduction in ATP synthesis and cell death (Maioli et al. 2012). Damage to plasma membranes can also occur as was previously demonstrated with erythrocytes subjected to alkaloids from P. juliflora (Kandasamy et al. 1989).

There is no specific treatment for $P$. juliflora poisoning in ruminants. The treatment would be successful only when started in the early stages of the disease, and consists of the administration of rumen contents and a balanced diet containing soluble structural carbohydrates. Sheep appear to be more resistant to poisoning considering that it took 21 months of pod consumption for two out of 500 sheep to show clinical signs. In the case of cattle and goats grazing in areas with mesquite, it is suggested that the animals do not remain in these pastures for longer than 60 days at one time.

Acknowledgements.- This work was supported by National Institute for Science and Technology for the Control of Plant Poisonings, National Council of Scientific and Technological Development (CNPq Grant: 573534/2008-0).

\section{REFERENCES}

Ahmad A., Ali Khan K., Ahmad V.U. \& Qazi S. 1986. Antibacterial activity of juliflorine isolated from Prosopis juliflora. Planta Med. 1:285-288.

Ahmad A., Ali Khan K. \& Ahmad V.U. 1991. Study on pharmacokinetics of juliflorine in rabbits and chick embryonated eggs. Pak. J. Pharm. 8:1-7.

Ahmad V.U., Sultana A. \& Qazi S. 1989. Alkaloids from the leaves of Prosopis juliflora. J. Nat. Prod. 52:497-501.

Câmara A.C.L., Costa N.A., Riet-Correa F., Afonso J.A.B., Dantas A.F.M., Mendonça C.L. \& Souza M.I. 2009. Spontaneous poisoning in cattle by mes- quite beans Prosopis juliflora (Leg. Mimosoideae) in Pernambuco. Pesq. Vet. Bras. 29:233-240.

Kandasamy A., William S. \& Govindasamy S. 1989. Hemolytic effects of Prosopis juliflora alkaloids. Curr. Sci. 58:142-144.

Kingsbury J.M. 1964. Poisonous Plants of the United States and Canada. Prentice-Hall, Englewood Cliffs, New Jersey, p.349-351.

Lima E., Riet-Correa F., Amorin S.L. \& Sucupira Júnior G. 2004. Poisoning by the pods of Prosopis juliflora (mesquite beans) in goats in northeastern Brazil. Pesq. Vet. Bras. 24:36-37.

Lopes S.T.A., Biondo A.P.S. \& Santos A.P. 2007. Manual de Patologia Clínica Veterinária. $3^{\mathrm{a}}$ ed. Departamento de Clínica de Pequenos Animais, UFSM, Santa Maria, p.5-45.

Maioli M.A., Lemos D.E.C.V., Guelfi M., Medeiros H.C.D., Riet-Correa F., Medeiros R.M.T., Barbosa-Filho J.M. \& Mingatto F.E. 2012. Mechanism for the uncoupling of oxidative phosphorylation by juliprosopine on rat brain mitochondria. Toxicon 60:1355-1362.

Pessoa A.F.A., Miranda-Neto E.G., Pessoa C.R.M., Simões S.V.D., Azevedo S.S. \& Riet-Correa F. 2012. Acute abdomen in equidae in the semiarid of the Brazilian Northeast. Pesq. Vet. Bras. 32:503-509.

Riet-Correa F., Riet-Correa G. \& Schild A.L. 2002. The importance of clinic exam for neurologic diagnostic of diseases in ruminant and horses. Pesq. Vet. Bras. 22:161-168.

Riet-Correa F., Andrade F.R.M., Carvalho F.K.L., Tabosa I.M., Galiza G.J., Bernardino N., Simões S.V.D. \& Medeiros R.M.T. 2012. Use of Prosopis juliflora pods as food for sheep and goats. Pesq. Vet. Bras. 32:987-989.

Silva M.A. 1988. Botany, taxonomy and distribution of the Genus Prosopis L. In: Habit M.A. \& Saavedra J.C. (Eds), The Current State of Knowledge on Prosopis juliflora. Plant Production and Protection Division, FAO, Rome. $172 \mathrm{p}$

Tabosa I.M., Souza J.C.A., Barbosa-Filho J.M., Almeida R.N., Graça D.L. \& Riet-Correa F. 2000. Neuronal vacuolation of the trigeminal nuclei in goats caused by the ingestion of Prosopis juliflora pods (mesquite beans). Vet. Human Toxicol. 42:155-158.

Tabosa I.M., Riet-Correa F., Barros S.S., Summers B.A., Simões S.V.D., Medeiros R.M.T. \& Nobre V.M.T. 2006. Neurohistologic and ultrastructural lesions in cattle experimentally intoxicated with the plant Prosopis juliflora. Vet. Path. 43:695-701. 